\title{
Evaluation of Gojiextract and Charcoal as Antioxidant on T-2 Toxin Administration Onliver Male Mice
}

\author{
Abdulbasit I. I. Al-Sien, Madeha N. Al-Seni \\ Department of Biochemistry, Faculty of Science, King Abdulaziz University, Jeddah, KSA \\ Email: elsawinagwa@yahoo.com
}

Received 27 September 2014; revised 22 October 2014; accepted 12 November 2014

Copyright (C) 2014 by authors and Scientific Research Publishing Inc.

This work is licensed under the Creative Commons Attribution International License (CC BY). http://creativecommons.org/licenses/by/4.0/

c) (i) Open Access

\begin{abstract}
With a view to study the effects of exposure to T-2 toxin and their amelioration by Goji extract or charcoal, male mice were treated with a sublethal dose of T-2 toxin $(200 \mu \mathrm{g} / \mathrm{kg} \mathrm{B}$.W $)$ intraperitoneally. T-2 Toxin showed an increase $(P \leq 0.05)$ in blood of ALT, ALP, Total Lipids, TAS, and TNF. These were decreased by Goji extracts or charcoal, and were improved partially by the two treatments. It is concluded that the treatment of rats with Goji extract or charcoal ameliorated the adverse effects of toxins but the results suggest that Goji extracts may be used as antioxidant and antidote rather than charcoal for $\mathrm{T}-2$ Toxin in mice.
\end{abstract}

\section{Keywords}

T-2 Toxin, Goji Extract, Activated Charcoal, Liver, Serum, Mice

\section{Introduction}

T-2 Toxin mycotoxin [3 $\alpha$-hydroxy, $4 \beta$, 15-diacetoxy-8 $\alpha$ (3ethylbutryloxy) 12, 13-epoxytrichothece-gene] (Figure 1) is a toxic metabolic produced by certain Fusarium species. This toxin is one of the most important trichothecene mycotoxins occurring naturally in Agricultural products [1] and is involved or conjecturally Associated with serious field cases of human toxicoses [2]. In Egypt, T-2 Toxin has been detected in seeds and grains [3]. Activated charcoal was used to prevent toxicosis and death in rats given T-2 Toxin [4]. Also, [5] used Goji extracts as antioxidants on the adverse effects of roridin $\mathrm{E}$ as mycotoxin.

In addition [6] used Activated charcoal as antioxidants and antidote for trichoverrins [A \& B] [1:1] in rats. The primary aim of this investigation was to describe biochemical changes of the liver as a result of administrating mixture Albino male mice from T-2 toxin and to evaluate the possible protective effect of Goji (Figure 2) 


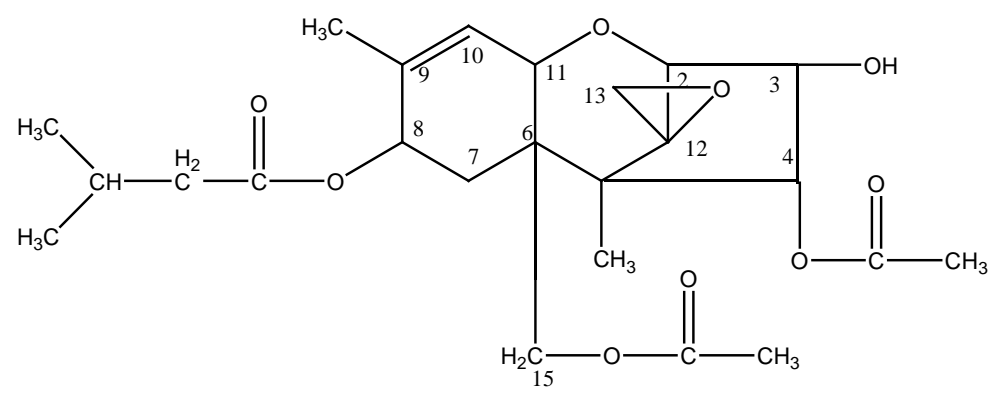

Figure 1. Chemical structure of T-2 toxin.

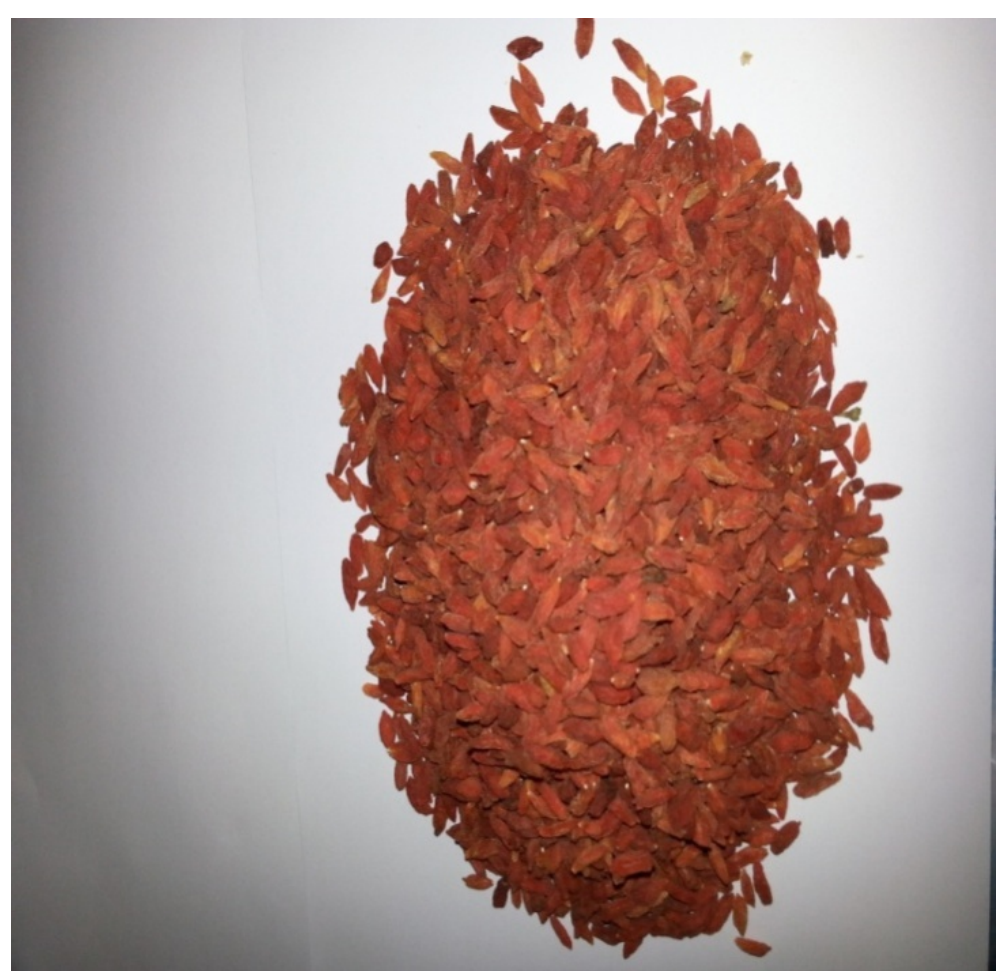

Figure 2. Gogi Berry fruits.

extracts and charcoal as also antioxidants on T-2 toxin induced hepatotoxicity in male adult mice.

\section{Materials and Methods}

T-2 Toxin obtained from sigma chemical Co.ST. Louis, USA. Activated charcoal was obtained from BDH [England] Goji dried fruits were collected from china market. Other kits were from Biovision, USA.

The study was performed on inbreeding 6 weeks white male mice MF1 (40 animals] each weights 29 - 32 g. Animals were divided into4 groups (10 mice each) and were subjected to the following schedule of treatments.

Control: which was gavage fed with propylene glycol and left for 2 weak before dissection.

T1: was gavage fed with a single dose of $200 \mu \mathrm{g} / \mathrm{kg}$ B.W of T-2 toxin, dissolved in propylene glycol and kept on normal feed for 2 weeks.

T2: was gavage fed with a single dose of $200 \mu \mathrm{g} / \mathrm{kg}$ B.W (T2 Toxin) and was followed immediately by charcoal at $1 \mathrm{~g} / \mathrm{kg} \mathrm{B}$. W but left for 2 weeks.

T3: was gavage fed with a single dose of $200 \mu \mathrm{g} / \mathrm{kg}$ of T-2 toxin and was followed crude water extract of Goji (2 $\mathrm{mg} / \mathrm{kg}$ ) using Gastric tube in all groups for 2 weeks.

After 2 weeks of injection, all rats were anesthetized using ether, blood samples were collected from the heart and serum was separated by centrifugation at $5000 \mathrm{rpm}$ for 10 minutes and stored at $-20^{\circ} \mathrm{C}$ until analysis. En- 
zymatic activity of ALT was assessed as described by [7], level of alkaline phosphate (ALP) was measured according to [8]. Also, total serum lipids was estimated by The method of Frings et al. [9]. In addition, total antioxidants (TAS) concentration was measured according to [10], while ferritin was measured according to [11]. In addition, TNF was determined according to the method of Beutler and Ceramic [12].

\section{Results and Discussion}

The present study determine the effect of T-2 toxin in male mice and has focused on its effect on liver function and evaluate the possible role of charcoal and Goji extract in reversing T-2 toxin toxicity. The data in Table 1 indicate that the treatment of male mice with T2 toxin in treated one (T1) produced an increase ( $p>0.05)$ in ALT, ALP, total lipids, TAS and Ferritten (Table 1) where as in TNF was highly significance than control groups. These results may be attributed to the varying toxic effect of T2 toxin. The above data (Table 1, Figures 3-8) are in agreement with the results obtained by Ueno [1], who reported that the trichothecenes have highly toxic effects due to a 9, 10 double bond and a 12, 13 epoxide group [13], responsible for its toxicological activity [14].

It also prevents polypeptide chain initiation or elongation by interaction with eukaryotic $60 \mathrm{~S}$ subunit [large nucleoprotein subunit of ribosome] and interaction with the enzyme peptidyl transferase. This interaction leads to varying degrees of inhibition of peptide bond formation [13].

Lyciumbarbarum, as well known traditional Chinese medicinal herb, possesses diverse biological activities and pharmacological functions including reducing blood glucose, anti-aging, immune modulating, anticancer, antifatigue, and serum lipids [15] and [16]. Lyciumbarbarum extrat as effective free radical scavengers, was demonstrated and have antioxidant activity [17]. On the other hand, mice withT-2 toxin plus Goji [T3] were significantly decreased in all parameters as compared to the treated 1 with toxin due to the ability of goji for absorption or elimination of the mycotoxin or inhibiting its transformation resulting in the increase of its toxicity [18]. Lyciumbarbarum (Goji) contain pharmacologically Active constituents that offer a vaiety of indications that affect different organs of the body [19]. Also, the interaction may occur between joji and mycotoxin where joji act as antioxidants [5] [20] [21]. Otherwise, treatment of mice with T-2 toxin was caused an increase in the mean value in Alt, Alp, total lipids, TSA and TNF but decreased in ferritten than control groups. Also, All T-2 mycotoxin groups caused a decrease in the mean values of ferritten but the Goji ameliorate the value of ferritten than T2 toxin group.

Ferritten dependant oxidative damage which may be involved in the pathogenesis of disease which increased total antioxidants (enzymatic or non enzymatic) formation occurs and the toxicity of T-2 toxin that increases antioxidanta production to mobilize ferritin. Thus, this suggestion is in agreement with [22] and [23], or may be as the result of increases urinary excretion, decreases ferritin levels and reduces liver iron in the majority of chronically transfused iron loaded patients [24]. All T-2 mycotoxin plus charcoal produced an decrease in the amount value $(\mathrm{p}>0.05)$ in Alt, ALP, total lipids, TAS, TNF compared than treated [T1] group but it was non significance in TAS [total antioxidants, otherwise, the T-2 toxin groups produced an increase ( $p>0.05)$ in all parameters but give highly significance ( $\mathrm{p}>0.001$ ) in TNF than control group. It was reported that the charcoal is an effective method for the prevention of poisoning in mice from mycotoxin [6]. The previous data confirms that Goji extract was considered as the strong antioxidant rather than activated charcoal due to Goji (Lyiciumbarbarium)

Table 1. Effect of T-2 Toxin (200 mg/Kg) (T1) alone and in combination with charcoal (19/kg) (T2) \& also with Goji extract $(5 \mathrm{~g} / \mathrm{kg}) \mathrm{T} 3$ on some biochemical parameters in serum of male mice.

\begin{tabular}{ccccc}
\hline Groups Parameters & Control & T1 & T2 & T3 \\
\hline ALT U/L & $30.12 \pm 0.14$ & $35.5 \pm 0.5^{*}$ & N.S $33.5 \pm 0.2$ & N.S $30.73 \pm 0.14$ \\
ALP U/L & $3.60 \pm 0.03$ & $4.9 \pm 0.0^{*}$ & $4.09 \pm 0.63^{*}$ & N.S $3.5 \pm 0.02$ \\
Total lipids g/l & $1.53 \pm 0.01$ & $2.11 \pm 0.02^{*}$ & $2.11 \pm 0.26^{*}$ & N.S $1.56 \pm 0.12$ \\
TAS $\mathbf{~ m m o l / l ~}$ & $0.18 \pm 0.02$ & $0.29 \pm 0.03^{*}$ & N.S $0.3 \pm 0.02$ & N.S $0.02 \pm 0.03$ \\
Ferritin $\mathbf{~ g / / m l ~}$ & $0.19 \pm 0.091$ & $0.13 \pm 0.09^{*}$ & $0.11 \pm 0.091^{*}$ & N.S $0.2 \pm 0.09$ \\
TNF $\mathbf{~ p g / m l ~}$ & $35.04 \pm 0.012$ & $51.74 \pm 0.4^{* *}$ & $46.3 \pm 0.12^{*}$ & N.S $36.4 \pm 0.2$ \\
\hline
\end{tabular}

Data are expressed as mean $\pm \mathrm{SE}$, Number of sample in each group is 10. Significant change in comparison between control and treated groups, ${ }^{* *}$ Highly significant $(\mathrm{p} \leq 0.01)$, ${ }^{*}$ Significant at $\left.0.01<\mathrm{p} \leq 0.05\right)$, N.S $=$ Non significant at $\mathrm{p}>0.05$. 


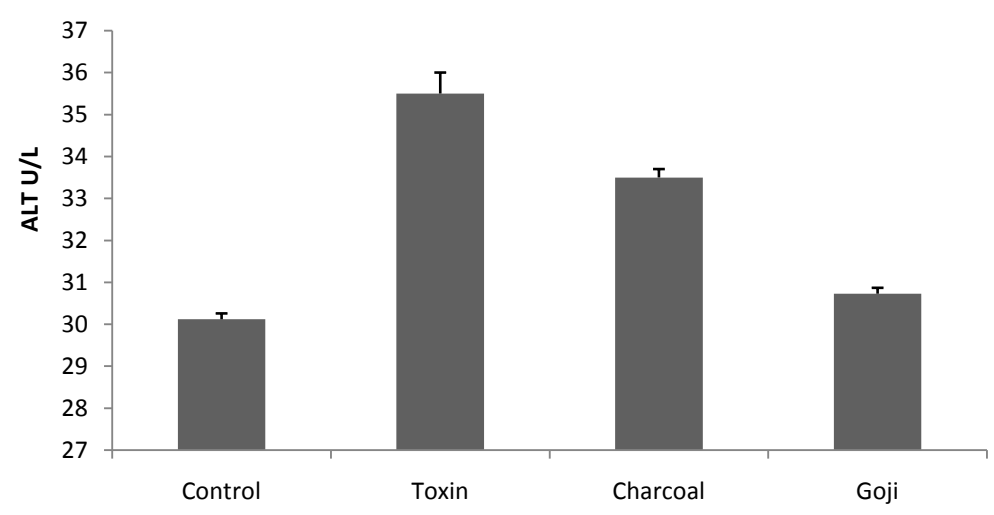

Figure 3. Effect of T2 Toxin $(200 \mathrm{mg} / \mathrm{Kg})$ alone and in combination with charcoal or Goji extract on ALT (U/L) of male mice serum.

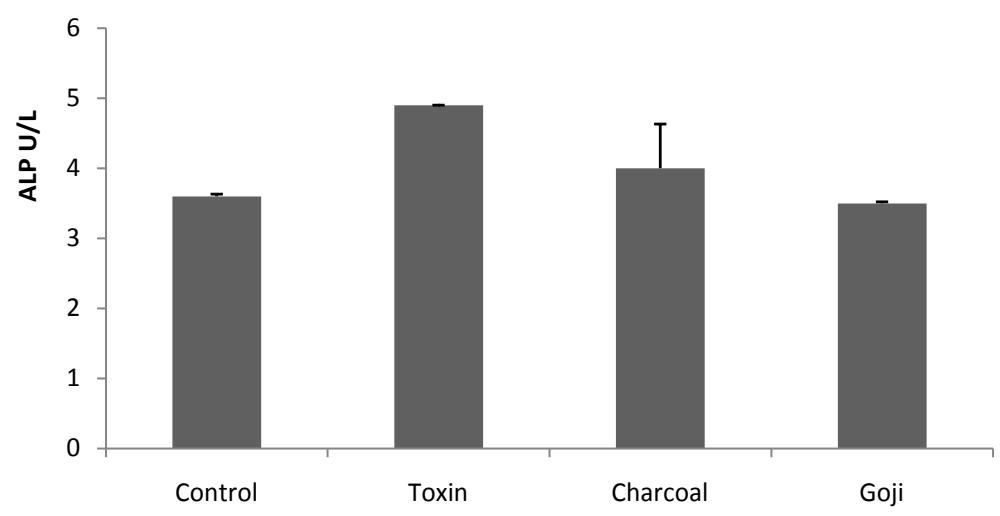

Figure 4. Effect of T2 Toxin $(200 \mathrm{mg} / \mathrm{Kg}$ ) alone and in combination with charcoal or Goji extract on ALP (U/L) of male mice serum.

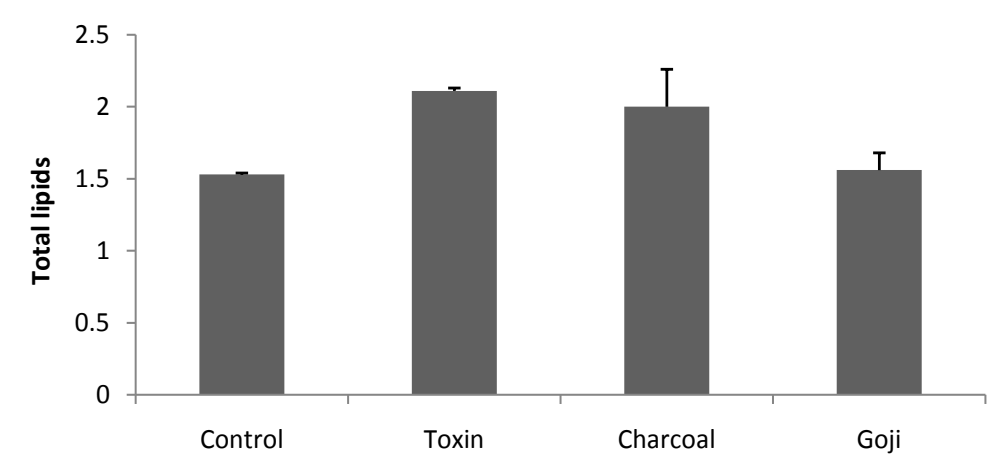

Figure 5. Effect of T2 Toxin $(200 \mathrm{mg} / \mathrm{Kg})$ alone and in combination with charcoal or Goji extract on Total lipids ( $\mathrm{g} / \mathrm{l})$ of male mice serum.

improves in vivo antioxidant biomarkers in serum of healthy adults and increased antioxidant efficacies in humans by stimulating endogenous factors and suggest that continued use prevent or reduce free radical-related conditions [25] and the surface area of Goji was larger than the surface area of charcoal and this lead to more adsorption of toxin substance. Further studies are required to determine the effect of these two substances as antioxidants and their mechanism against toxins in future researches.

\section{Conclusion}

Mycotoxins are small and quite stable molecules which are extremely difficult to remove or eradicate, and 


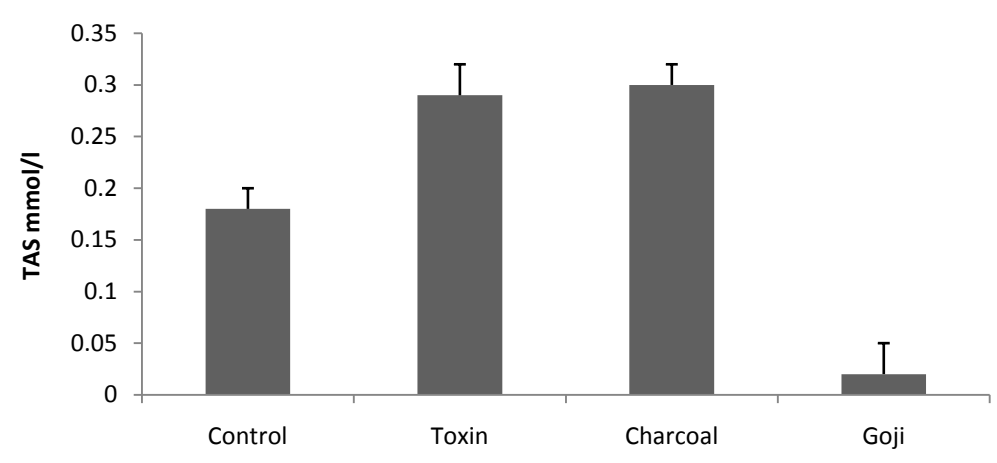

Figure 6. Effect of T2 Toxin $(200 \mathrm{mg} / \mathrm{Kg}$ ) alone and in combination with charcoal or Goji extract on TAS (mmol/l) of male mice serum.

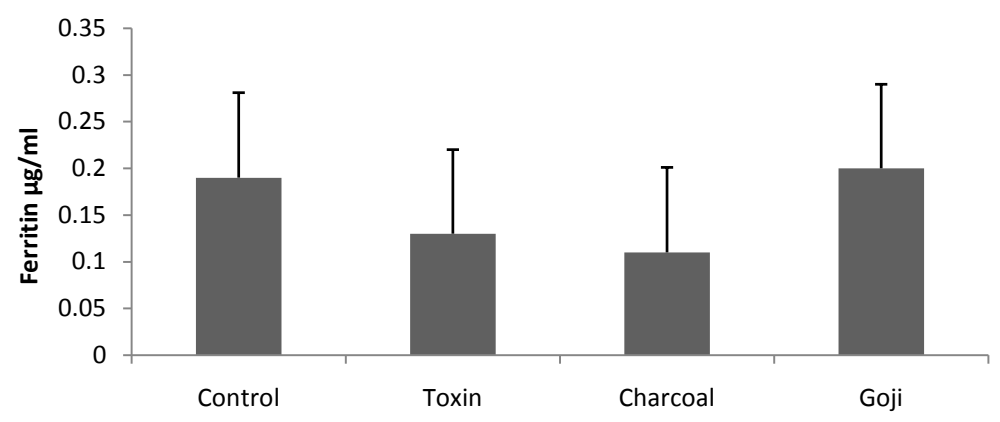

Figure 7. Effect of T2 Toxin $(200 \mathrm{mg} / \mathrm{Kg}$ ) alone and in combination with charcoal or Goji extract on Ferritin $\mu \mathrm{g} / \mathrm{ml}$ of male mice serum.

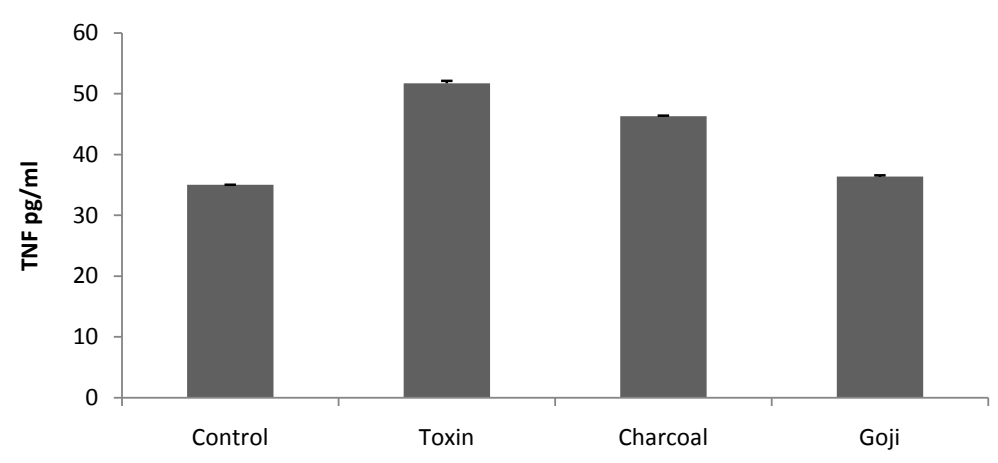

Figure 8. Effect of T2 Toxin $(200 \mathrm{mg} / \mathrm{Kg}$ ) alone and in combination with charcoal or Goji extract on TNF $(\mathrm{mg} / \mathrm{ml})$ of male mice serum.

which enter the feed chain while keeping their toxic properties. Mycotoxins of major concern as feed contaminants and one of the strategies for reducing the exposure to mycotoxins is to decrease their bioavailability by including various mycotoxin-adsorbing agents in the compound feed, which leads to a reduction of mycotoxin uptake as well as distribution to the blood and target organs. It is found that treatment of rats with Goji extract or charcoal ameliorated the adverse effects of mycotoxins. The results suggest that Goji extracts may be used as antioxidant and antidote rather than charcoal for T-2 Toxin in mice.

\section{References}

[1] Ueno, Y. (1983) Trichothecenes, Chemical, Biological and Toxicological Aspects. Kodansha Ltd. and Elsevier Science Publishers, Amsterdam, 163-170.

[2] Szathmary, C.I., Mirocha, C.J., Polyusik, M. and pathre, S.V. (1976) Identification of Mycotoxins Produced by Species of Fusarium and Stachybotrys Obtained from Eastern Europe. Applied Environmental Microbiology, 32, 579-584. 
[3] El-Magharaby, O.M.O., Saber, S.M., and Abdoul Nasr, M.B. (1992) Contamination of Pea (Pismsativuma L) Seeds by Fungi, Mycotoxins and Seeds by Fungi, Mycoyoxins and Resistance of Cultivar to Mycotoxin Accumulation. Sohag Pure and applied Science Bulletin, Faculty of Science, Egypt, 8, 137-155.

[4] William, B and Paulam, B.S. (1986) Activated Charcoal Preventing Unnecessary Death by Poisoning. J. Food Animal Prac., 2, 73-77.

[5] Al Seeni, M.N. (2011) Goji Extract as Antibacterial Agent and 5 Antioxidant on Roridin E Induced Hepato Toxicity in Malerat. J. Int. Environmental Application \& Science, 6, 136-140.

[6] El-Sawi, N.M. (2003) Effect of Activated Charcoal on Trichoverrins (A \& B) Toxin Administration on Rat Liver and Serum Protein. Journal of Applied Animal Research, 23, 175-184. http://dx.doi.org/10.1080/09712119.2003.9706419

[7] Reitman, S. and Frankel, L. (1957) A Colorimetric Method for the Determination of Serum Glutamic Oxaloacetic and Glutamic Pyruvic Transaminases. American Journal of Clinical Pathology, 28, 56-63.

[8] Moss and Henderson, A.R. (1999) Clinical Enzymology. In: Burtis, C.A. and Ashwood, E.R., Eds., Tietz Textbook of Clinical Chemistry, 3rd Edition, Saunders, Philadephia, 617-677.

[9] Fringes, C.S., Ferdley, T.W., Dunn, R.T. and Queen, C.A. (1972) Improved Determination of Total Serum Lipids by the Sulfophos Vanillin Reaction. ClinChem., 18, 673-674.

[10] Miller, N.J., Rice-Evans, C., Davies, M.J., Gopinathan, V. and Milner, A. (1993) A Noval Method for Measuring Antioxidant Capacity and Its Application to Monitoring the Antioxidant Status in Premature Neonates. Clinical Science (London), 84, 407-412.

[11] Young, D.S. (1995) Effects of Drugs on Clinical Laboratory Test. 4th Edition, AACC Press, Washington.

[12] Beutler, B. and Cerami, A. (1987) Cachectin: More than a Tumor Necrosis Factor. New England Journal of Medicine, 316, 379-385. http://dx.doi.org/10.1056/NEJM198702123160705

[13] Yang, G.H., Jarvis, B.B., Chung, Y.J. and Pestka, J.J. (2000) Apoptosis Induction by the Satratoxins and Other Trichothecene Mycotoxins: Relationship to ERK, p38 MAPK and SAPK/JNK Activation. Toxicology and Applied Pharmacology, 164, 149-160. http://dx.doi.org/10.1006/taap.1999.8888

[14] Sudakin, D.L. (2003) Dietary Aflatoxin Exposure and Chemoprevention of Cancer: A Clinical Review. Clinical Toxicology, 41, 195-204. http://dx.doi.org/10.1081/CLT-120019137

[15] Gao, X.M., Xu, Z.M. and Li, Z.W. (2000) Traditional Chinese Medicines. Peoples Health Publishing House, Beijing, 1832-1850.

[16] Gan, L. and Zhang, S.H. (2003) Effect of Lycium barbarum Polysaccharides on Antitumor Activity and Immune Function. Acta Nutrimenta Sinica, 25, 200-202.

[17] Luo, Q., Cai, Y., Yan, J., Sun, M. and Carke, H. (2004) Hypoglycemic and Hypolipidemic Effects and Antioxidant Activity of Fruit Extracts from Lycium barbarum. Life Sciences, 76, 137-149. http://dx.doi.org/10.1016/j.lfs.2004.04.056

[18] Buck, W.B. (1991) Trichothecene Mycotoxins. In: Keeler, R.F. and Tu, A.T., Eds., Handbook of Natural Toxins, Vol. 6, Toxicology of Plant and Fungal Compounds, Marcel Deckker, Inc., New York, 523-555.

[19] Leung, H., Hung, A., Hui, A.C.F. and Vhan, T.Y.K. (2008) Warfarin Overdose Due to the Possible Effect of Lycium barbarum L. Food and Chemical Toxicology, 46, 1860-1862. http://dx.doi.org/10.1016/j.fct.2008.01.008

[20] Liu, M., Tan, H., Zhang, X., Liu, Z., Cheng, Y., Wang, D. and Wang, F. (2014) Hematopoietic Effects and Mechanisms of Fufang E Jiaojiang on Radiotherapy and Chemotherapy Induced Myelosuppressed Mice. Journal of Ethnopharmacology, 4, 10-15.

[21] Zhong, Y., Shahidi, F. and Naczk, M. (2013) Phytochemicals and Health. Benefits of Goji Berries, 133-144.

[22] Reif, D.W. (1992) Ferritin as a Source of Iron for Oxidative Damage. Free Radical Biology and Medicine, 12, 417-427. http://dx.doi.org/10.1016/0891-5849(92)90091-T

[23] ELsawi, N.M., Qusti, S.Y., Abo-Khatwa, A.N., Aldajani, W. and Ali, S.S. (2010) Biochemical Investigation on Roridin a Toxin and Thymoquinone Antidote on Mouse Liver. Journal of International Environmental Application \& Science, 5, 703-712.

[24] Kontoghiorghes, G.J., Pattichi, K., Hadjigavriel, M. and Kolnagou, A. (2000) Transfusional Iron Overload and Chelation Therapy with Deferoxamine and Deferiprone (L1). Transfusion Science, 23, 211-223. http://dx.doi.org/10.1016/S0955-3886(00)00089-8

[25] Amagase, H. and Nance, D.M. (2008) A Randomized Double-Blind, Placebo-Controlled, Clinical Study of the General Effects of a Standardized Lycium barbarum (Goji) Juice, Gochi. The Journal of Alternative and Complementary Medicine, 14, 403-412. http://dx.doi.org/10.1089/acm.2008.0004 
Scientific Research Publishing (SCIRP) is one of the largest Open Access journal publishers. It is currently publishing more than 200 open access, online, peer-reviewed journals covering a wide range of academic disciplines. SCIRP serves the worldwide academic communities and contributes to the progress and application of science with its publication.

Other selected journals from SCIRP are listed as below. Submit your manuscript to us via either submit@scirp.org or Online Submission Portal.
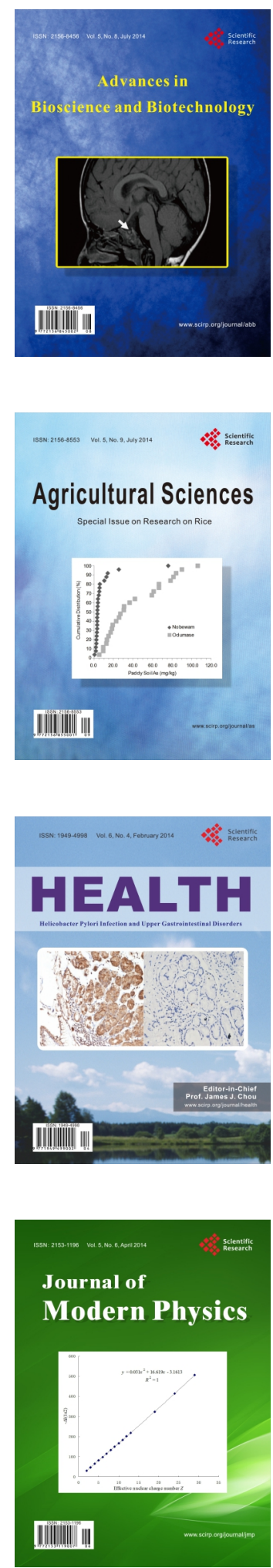
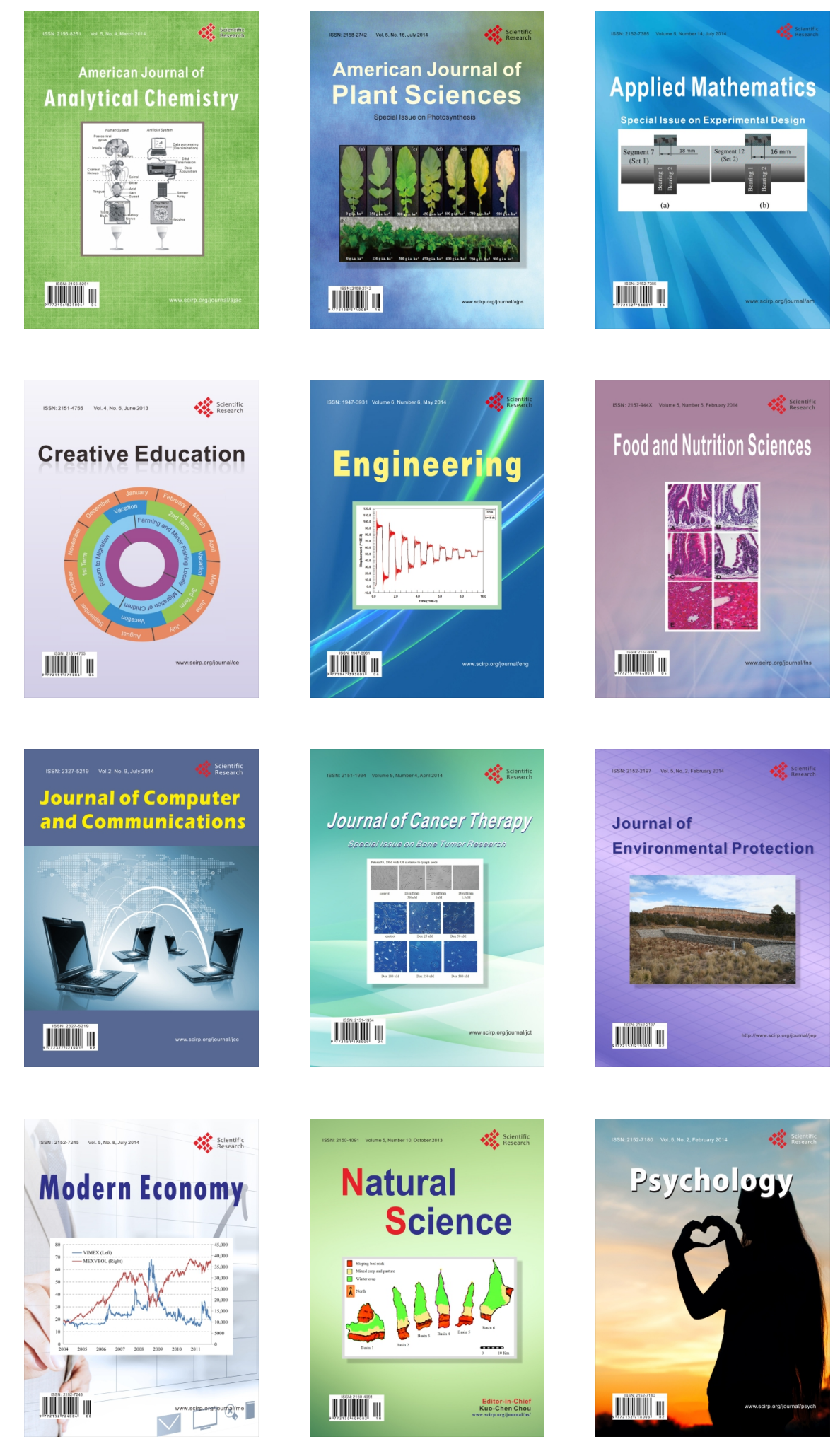